\title{
Investigating IFRS compliance in transitioning countries: A qualitative study
}

\author{
Silvia Petre ${ }^{\mathrm{a}, 1}$ and Nadia Albu \\ ${ }^{a}$ Bucharest University of Economic Studies, Romania
}

\begin{abstract}
Idea: The purpose of the paper is to investigate the institutional context in which companies' compliance with IFRS is created over time. Data: We collected financial and non-financial data from the Bucharest Stock Exchange website, from companies' website and from the media, for three pharma companies listed on the Bucharest Stock Exchange. We focused on the period 2013-2017, given that 2012 is the first year for the IFRS application in Romania in the individual accounts. Tools: We employed the EY (2012) Disclosure Checklist and the Dichotomous approach (Tsalavoutas, 2011) to determine the IFRS compliance index. We mobilize an institutional theory-based framework to analyze the IFRS compliance index. What's new? Our results indicate that the level of compliance is an organizational response to macro-, industry-, and organizational level factors. Moreover, companies face several pressures for compliance with different requirements, and choose to what pressures to comply first. Therefore, compliance with disclosure requirements from some IFRS is a piece in an organizational puzzle, so wider frameworks and analyses are needed to understand organizational responses. So what?: Companies respond with various levels of compliance in emerging economies such as Romania, and understanding the factors influencing compliance is of interest for regulators, auditors, and capital market participants. Contribution: We contribute with a qualitative, institutional-based study to a research stream dominated by archival methods, and bring complementary explanations for organizational levels of compliance with IFRS.
\end{abstract}

\footnotetext{
${ }^{1}$ Corresponding author: Silvia Petre, Bucharest University of Economic Studies, Romania: 6 Piața Romană, 1st District, Bucharest, 010374 Romania, tel: 021319 1900, email address: petresilvia11@stud.ase.ro
} 
Keywords: IFRS compliance, pharmaceuticals industry, institutional theory, emerging country

\section{JEL codes: M41}

\section{Introduction}

Globalization is considered to increase world trade and interaction, resulting in a growing development of the international financial markets, and hence, for companies, to a higher need for transparency, better quality of the financial reporting and to pressures to respond to increasing demands from the economic stakeholders, such as investors, regulators and financial analysts (Arnold, 2012; Glaum et al., 2013).

International standards such as IFRS are believed to address the above-mentioned expectations (Arnold, 2012; Houqe, 2018; Ionașcu et al., 2014; Navarro-Garcia \& Bastida, 2010). However, IFRS were initially deployed using the developed countries' model, which are characterized by common law and investors' protection (Albu et al., 2011; Houqe, 2018). These are the opposite traits of developing countries, which rather have a secrecy culture, less investor-oriented nature and are more tax driven (Larson \& Street, 2004; Mokhtar et al., 2018; Nurunnabi, 2015). Despite these facts, "most of the adopters of IFRS have been developing countries" (Houqe, 2018: 19), which have limited capacity and infrastructure, in terms of resources and expertise, to properly adopt internationally standards (Arnold, 2012). Therefore, investigating actual compliance with international standards in these jurisdictions is highly relevant for the researchers on the effects of globalization, but also for the countries subject to this kind of reforms, and for the international actors providing related advice.

Pressured by the international expectations, less developed countries embrace reforms and adopt international standards (Arnold, 2012). However, prior research emphasizes the importance of real conformity, especially since IFRS benefits are found to occur only in cases of compliance (Albu et al., 2011; Navarro-Garcia \& Bastida, 2010). McGee (cited in Mokhtar et al., 2018:3) emphasizes that "Adopting IFRS is one thing. Implementing them is something else. The mere fact that a government might adopt new accounting rules does not mean that they will be swiftly, efficiently and comprehensively applied and implemented throughout the economy". Given that compliance is a sensitive issue, we focus on an in-depth investigation of the institutional context influencing conformity levels.

The purpose of the paper is to investigate the institutional context in which companies' compliance with IFRS is created over time. We adopt an institutional approach for our investigation. We follow a multi-level institutional framework in 
line with Dillard et al. (2004) to allow for a wider discussion of the institutional factors contributing to the creation of compliance at company level. Dillard et al. (2004) advance that institutional pressures reside at the political and economic level, organizational field, and organizational level. Guerreiro et al. (2020) emphasize the importance of this approach in studying the implementation of IFRS and the resulting accounting practices.

We conduct our study in the context of Romania, but aim to inform other transitioning and emerging countries. Romania is a post-socialist transitioning country, with a small stock exchange (given that regularly there are only about 80 companies listed on the regulated market), which just became an emerging market. Therefore, the stock exchange listing is expected to provide less incentives and pressures for companies to comply with IFRS (Albu et al., 2019). Moreover, prior research indicates a high level of variability in compliance levels (Albu et al., 2013, 2014; Gorgan \& Gorgan, 2014) and a difficulty to identify relevant factors associated with disclosures, given the small sample sizes. In this context, we focus on a qualitative approach to discuss the institutional context in which compliance is created. Given the importance of the organizational field (industry) for our study, and to avoid differences between companies in this respect, we focus on the pharma industry. This industry proved to be relevant at European level (EFPIA, 2018) but as well at Romanian level, because of the difficulties the medical system faces. We are thus interested in the IFRS compliance in Romania in a very important industry, because it is expected that higher financial reporting quality involves less information asymmetry, more financing sources and increased international credibility (ICAEW, 2014). The standards which emerged as relevant ones for pharma industry are IAS 36 Impairment of assets and IAS 38 Intangible assets (Lavi, 2016; PwC, 2017).

We contribute to the literature by expanding the IFRS knowledge on compliance. Most of the research conducted in this area is empirical archival (e.g., Glaum et al., 2013), which, as a methodological approach, poses some issues in emerging economies. In their review of IFRS studies in emerging economies, Samaha and Khlif (2016) find very few studies investigating compliance with IFRS, with mixed results. Therefore, we respond to recent calls (Guerreiro et al., 2020) to employ institutional theory in investigating the IFRS practices.

This paper is organized as follows: Section 2 comprises the literature review; Section 3 - the context for IFRS in Romania, pharmaceutical industry in Romania and IFRS within this industry; Section 4 briefly introduces the theoretical framework; Section 5 describes the methodology employed for our research; Section 6 presents the results obtained and the last part synthesizes the conclusions. 


\section{Literature review}

\subsection{A review of the literature on IFRS compliance}

Starting 2005, the EU mandated listed companies to report their consolidated accounts according to IFRS (following EU 1606/2002 issued by the European Commission). The support for IFRS is actually a global one, given that $87 \%$ of the jurisdictions worldwide require IFRS "for all or most domestic publicly accountable entities (listed companies and financial institutions) in their capital markets" (IFRS Foundation, 2018). IFRS are designed to follow the needs of capital markets from developed countries (Mokhtar et al. 2018; Zehri \& Chouaibi, 2013).

But globally, and in the EU as well, a significant number of the IFRS adopters represents transitioning, emerging economies, with institutional contexts different than the ones of developed countries. These countries are found to share some common institutional features, as much of the literature in international accounting suggests. Reviewing this literature, Houqe and Monem (2016) identify the following common features: low protection of investor's economic interest, low level of financial transparency, elevated corruption levels, and "weak rule of law".

When developing countries adopted IFRS, their institutional context opened rooms for variation in practice. Therefore, there are calls to study the IFRS use in developing countries (Houqe 2018; Mokhtar et al. 2018; Samaha \& Khlif, 2016), especially due to the increasing number of emerging economies having applied or intending to increase the scope of IFRS application (Zehri \& Chouaibi, 2013). Albu et al. (2011) argue that "merely changing accounting standards without implementing profound changes in capital market regulations, economic development policy or corporate governance may not yield desired results in the financial reporting quality". Prior research indicates that particularly the level of law enforcement and protection granted to the interests of the company's shareholders and investors, in which the internal audit department plays an important role (Alzeban, 2018; Navarro-Garcia \& Bastida, 2010) is critical in the case of emerging economies. Mokhtar et al. (2018) also argue that "compliance with the requirements of IFRS will be a major concern for those [developing] countries since the lack of financial reporting infrastructure, such as regulatory enforcement, may cause a significant non-compliance with IFRS". Hope (2003) stresses the importance of enforcement, since certain standards allow more than one accounting choice, which can increase the incidence of creative accounting and earnings' management (Carlin \& Finch, 2010; Houqe, 2018; Navarro-Garcia \& Bastida, 2010).

IFRS compliance is important for emerging countries, since the benefits expected to flow from their adoption materialize only in cases of compliance. These expected benefits include: increased comparability in the context of worldwide trade, which 
would lead to an increased level of foreign direct investments, lower cost of capital due to more credibility assigned to financial reporting packages, overall higherquality information disseminated in the economic environment useful for a wide range of stakeholders (Houqe, 2018).

Prior research investigating the level of compliance finds multiple research approaches, contributing to the compliance literature with various types of insights. The researchers employing quantitative methods to determine the level of compliance with IFRS employed one of the following approaches: the unweighted index, also known as "Cooke's dichotomous approach" (Glaum et al., 2013; Juhmani, 2017; Kwame Agyei-Mensah, 2017; Mazni et al., 2012; Tsalavoutas, 2011) and the Partial Compliance index (Al-Shiab, 2003 cited in Tsalavoutas et al., 2010; Mazni et al., 2012; Tsalavoutas et al., 2014).

Studies have shown that if the dichotomous approach is used, the level of identified compliance is higher than if the Partial compliance method is used. The unweighted index involves the computation of a list of required disclosures by the researcher, with the items being evaluated as 1, if the company is compliant and 0 if it is not. This method is considered by researchers (Mazni et al., 2012; Tsalavoutas et al., 2010) to unrightfully give a higher importance to the standards which have more requirements to comply with and consequently a lower weight to standards which have less specifications to follow. The Partial compliance index, on the other hand, allows for the compliance assessment to be performed standard by standard, due to the fact that it is obtained by initially calculating a "compliance index for each standard", which is then "divided by the total number of relevant, applicable standards for each company" (Al-Shiab, 2003 cited in Tsalavoutas et al., 2010).

On the other hand, researchers employing qualitative methods use questionnaires, surveys and interviews with academics, regulators, audit professional, financial managers and other relevant actors to investigate compliance (Ballas et al. 2010; Nurunnabi, 2015; Uyar et al., 2016). Moreover, Guerreiro et al. (2020) call for more research under an institutional-based approach to shed more light on the complex IFRS processes and practices.

Both quantitative and qualitative researchers bring explanations for the level of compliance noticed, by identifying and discussing various institutional factors. These factors are usually discussed as being country- or company- related. For example, Houqe and Monem (2016) demonstrated that the extent of IFRS experience and disclosure are directly impacted by the perceived corruption found in a country. Corruption not only affects the IFRS matter, but as well the economic growth, the level of foreign direct investments (positively correlated with IFRS adoption and compliance, as per Houqe, 2018) and the foreign exchange rate. Corruption is demonstrated in various research paper as a determinant of both IFRS adoption and compliance (Bova \& Pereira 2012; Glaum et al. 2013; Nurunnabi, 2015). Culture is 
a frequently mentioned aspect among IFRS-based research papers. Institutional theory itself stresses the importance of cultural factors and define culture as a "communications system that transfers, from one time period to the next, social knowledge about institutions, their formal and informal rules" (Albu et al. 2011). Glaum et al. (2013) and Nurunnabi (2015) include as well cultural factors in their research methodologies, and also other cultural factors are found in the literature, such as secrecy (Albu et al. 2011; Mokhtar et al. 2018) and conservatism (Glaum et al. 2013). Capital market's size is another country-level factor which influences IFRS adoption and compliance (Glaum et al., 2013; Procházka \& Pelák, 2015; Zehri $\&$ Chouaibi, 2013).

The company-level factors which influence IFRS compliance include entity size for example (Glaum et al., 2013; Navarro-Garcia \& Bastida, 2010; Zehri \& Chouaibi, 2013; Uyar et al., 2016) and firm's profitability (Bepari et al., 2014; Juhmani, 2017), results showing that larger and/or more profitable companies have higher levels of compliance. Moreover, many studies find that audit is important in IFRS compliance, either in the form of audit committees presence and independence (Kwame Agyei-Mensah, 2017), the internal audit department's size or the level of professional training (Alzeban, 2018; Juhmani, 2017); or the collaboration with a Big 4 audit company for assurance on IFRS compliance (Ben Salem, 2017; Glaum et al., 2013; Nurunnabi, 2015; Tsalavoutas et al., 2010). The listing status has also been associated with a positive level of IFRS compliance as per Uyar et al. (2016), while cross-listing is found to be associated with improvements in compliance (Tsalavoutas et al., 2014). Resources' training (both accountants and auditors) is a factor often mentioned in consulted studies (Ballas et al., 2010; Mokhtar et al., 2018; Nurunnabi, 2015) in the sense that it can be a source of increased costs, but as well an opportunity to better implement IFRS.

In their review of IFRS in emerging economies, Samaha and Khlif (2016) find that previous studies employed signaling theory, agency theory, political process theory and capital need theory to explain compliance levels. Some studies find that the type of auditor, leverage, and size are associated with disclosure levels, and that there are mixed results concerning profitability, internationality, and ownership dispersion. Moreover, authors conclude that the relevance of the theories investigated is limited in investigating compliance in emerging economies, only the agency theory being mostly validated.

\subsection{IFRS in Romania}

The Romanian accounting context is characterized by many foreign influences over time, creating legacies that might still influence accounting practices, including the level of compliance with IFRS (Albu et al., 2014, 2019). Between 1947 and 1989, during the communist period, the accounting system was of Soviet origin, being characterized by a prominent secrecy in the financial reporting, the state being the only user of the accounting outputs, a rule-oriented approach and a focus on 
bookkeeping (Albu et al., 2011; Albu et al., 2014). After the fall of the communist regime, reforms were first made under French influences (Albu et al., 2011), but many of communist traits persisted, since "the new society will always contain many of the institutional elements that previously existed" (Lichtenstein, 1996, p. 247, cited in Albu et al., 2011).

After 2007, IFRS became mandatory for financial institutions and listed companies' consolidated accounts, while for the other entities, adoption remained voluntary. Starting 2012, international standards became mandatory for banks and all listed entities, in individual financial statements (Gorgan \& Gorgan, 2014; Ionașcu et al., 2014), in an effort to improve the quality of the information reported by the listed companies (Albu et al., 2014, 2019).

Previous studies on compliance with IFRS in Romania show that there is a significant variability across companies, suggesting that company-level variables are important. For example, Gorgan and Gorgan (2014) investigate compliance with IAS 38 for the years 2010, 2011, and 2012 and find an average value of about 0.50 (with the minimum value of compliance of 0 and maximum of 0.72 ). In their study, compliance is associated with auditor reputation. Gutierrez Ponce et al. (2016) investigate the level of compliance in 2012 for 58 listed companies for a list of IFRS and find a good level of compliance, around 80\%, with type of auditor and shareholder composition being significant factors for the levels of compliance. Albu et al. (2013) analyze compliance with IFRS 8 and find that $46.6 \%$ of the companies analyzed display a lack or low level of compliance. The factors associated with compliance are the ownership diffusion, type of the auditor, and the presence of institutional investors. Albu et al. (2014) discuss in a qualitative approach the overall response of listed companies to IFRS, and find cases of good compliance, partial compliance, formal (fake) compliance, or total lack of compliance. Their results point to the joint result of various institutional factors, including the type of ownership (national or foreign), ownership diffusion, visibility within the country, type of auditor, company's strategy and intentions, in shaping organizational responses to IFRS and the levels of compliance. Moreover, previous research points to some institutional factors at the country-level, such as enforcement, role of the audit report and opinion, and users' expectations, which influence as well the levels of compliance, and which changed over time (Albu et al., 2019). We take a more general approach in discussing compliance in a more recent period of time, to complement the existing findings.

\section{Theoretical framework: Institutional theory}

Institutional theory is a vast theoretical field, widely employed in management and organizational studies to explain change and organizations. Given the complex organizational processes around IFRS implementation and practice, Guerreiro et al. (2020) emphasize the importance of this theoretical stance in conducting IFRS 
studies, and call for future research in the area. Moreover, our theoretical choice is informed by previous literature on emerging economies. First, Samaha and Khlif (2016) find that various theoretical approaches have limited relevance to explain compliance variation (institutional theory is not part of the frameworks employed in the compliance studies reviewed). Second, an institutional-based approach is in line with the importance we ascribe in our study to the context (Albu et al., 2014).

Given the previous results from IFRS studies, we acknowledge that compliance is influenced by various factors, located at the company or country level. The institutional theory allows us to incorporate and refine this view. We follow Dillard et al. (2004) and take a multi-level representation of the social context. We therefore place our analysis at three levels: political and economic, organizational field, and organization. This allows us to conduct a more in-depth analysis, without privileging one level (Guerreiro et al., 2020), since the framework presents "institutionalization as a process recognized as political, reflecting the relative power of organized interests and the actors who mobilize around them" (Dillard et al., 2004: 510).

Dillard et al. (2004) present the economic and political level as the societal field providing the infrastructure, the laws, regulations, and acceptable codes of conduct. In our case, this societal level includes the overall country's infrastructure relevant for financial reporting, including the existence and strength of accounting and corporate governance laws, the level of enforcement, the size and development of the capital market, and the professionalism in using information.

The next societal level is the organizational field, which pertains to industrial norms and regulations, so it is mainly related to the industry. In many cases, industries dictate expected results from companies, development strategies, and ascribe particular logics (more prudent or risky, for example) to the field members.

Finally, the organizational level comprises all relevant aspects at the company level. Organizations filter the pressures and expectations received from the political and economic field and the organizational field and respond to them given their strategy, legitimacy expectations, and resources available. Therefore, "accounting reporting systems would have different characteristics, different objectives and different requirements" (Dillard et al., 2004: 528) across companies. Taking this view, we next present our methodological approach in investigating compliance in three Romanian companies from the pharma industry.

\section{Research approach}

\subsection{Research context}

\subsubsection{Pharma industry in Romania}

Progress in science and technology impacted in a significant manner pharma industry and this directly led to an improved life quality, which is, in the end, the true 
desiderate of the medical and research efforts (EFPIA report, 2018). Looking at a wide local context for Romania, research-based pharma industry can be of vital importance for Europe's economic growth and competitiveness, but challenges are equally significant and must be considered.

Thus, there is a stringent need to give the pharma industry the deserved importance, since problems in providing Romanian patients the needed medication on time (crises related to substances such as clonazepam, levodopa, acenocumarol, cisplatin etc.) arose in the past. There is a high potential of manufacturing in-house medicines, due to the fact that over the last 10 years, factories have been developed and modernized and yet, patients still wait for weeks for their treatments to be delivered via imports from other countries (Neagu, 2018). Economy overall is also affected, because of the pharma trade balance deficit, which in 2017 was 2.25 BLN EUR, meaning approximately $15 \%$ of the total deficit. Thus, the Industrial Drug Manufacturers Patronage in Romania (ro. Patronatul Producătorilor Industriali de Medicamente din România) claim that the pharma industry is recognized by the government as a strategic economic area of national interest, with the appropriate public measures (Neagu, 2018; Straut, 2018).

Among the companies identified by Cegedim (2018), cited in Dorobanțu (2018), can be found the following entities on which the special focus of this paper will be: Zentiva (which is part of Sanofi group - ranking number one, with 67 million units sold between July 2017 and June 2018), Antibiotice (with 31.7 million units sold between July 2017 and June 2018) and Biofarm (last one in ranking, with 20.2 million units sold in the same indicated period).

\subsubsection{IFRS and pharma industry}

Pharma industry is subject to many laws and regulations which ensure that the medicine testing and producing is safe and effective. However, adverse circumstances and situations may occur anytime, regardless the industry a company is part of. Causes can be found among recession, inflation, difficulties in obtaining financing etc. thus, assets' impairment treated in IAS 36 can have an impact on almost any industry. Despite relying on fair value concept, which has been long criticized, this standard is actually ensuring that the assets a company owns are not disclosed at a value which is higher than their recoverable amount, in which case an impairment loss has to be recognized. Additional information regarding the impairment tests (such as methodology and parameters used), impairment losses recognized and reversed are also required (Glaum et al., 2013).

Triggers for the need to book assets' impairment can consist in denials of approvals for developed medications or inappropriate acquisitions (Lavi, 2016). PwC (2017) 
also provide accounting treatments for the most common practices in the pharmaceutical businesses and assets impairment is included.

We thus consider that IAS 36 Impairment of assets is relevant for the pharma industry. Also, this standard is perceived as being one the most difficult standards in Romania (Larson \& Street, 2004) but as well in European companies (Glaum et al., 2013) or other countries (Mazni et al., 2012).

One of the most important activities in the pharma industry are related to research and development expenditures (EFPIA, 2018; Lavi, 2016; PwC, 2017). IAS 38 Intangible assets states that research expenses should be recognized directly in profit or loss statement, while development costs must be capitalized if they meet the criteria specified in the standard and amortized over its' finite life. The difference between the two types of costs resides in the entity's certainty that the future economic benefits are probable. The study conducted by Gorgan and Gorgan (2014) reveal that in the case of Romanian listed companies "there is a high level of noncompliance with IAS 38", due to the fact that few companies report according to the full disclosure requirements, many showing superficiality. The above-mentioned research does not contain a compliance assessment for pharmaceutical companies, which is a relevant chapter of the story that will be addressed in this study. Other relevant accounting elements or transactions refer to business combinations and provisions, which are not subject to our paper.

\subsection{Research methodology}

For the purpose of this paper we employ a qualitative research approach, particularly because organizations and their environment are not detached from one another, but are rather connected and interdependent (Zilber, 2002 cited in Albu et al., 2014), which urges us to consider all complexities. However, we complement the methodology by also using a quantitative technique, which allows the assessment of the companies' financial reportings' compliance degree. In this way we create a relationship with the quantitative archival studies as well.

We conduct our study on three companies from the pharma industry in Romania. We focus on the period post 2012, when IFRS became mandatory in Romania in the separate financial statements of listed companies. Some authors attributed the low level of compliance before 2012 to the dual reporting (IFRS and national GAAP) and to the difficulties faced by companies in consolidation (Albu et al., 2014, 2019). In our longitudinal research, we consider two important years when compliance is calculated: 2013, which is right after IFRS first time application and we consider companies might have had the chance to better understand the disclosure requirements and 2017, which was the most recent, finalized available year at the date we conducted this research, allowing a comprehensive assessment of the IFRS compliance evolution. 
First, we determine the level of compliance following the methodological approach usually employed in archival positivistic research, and we select a dichotomous method (Gorgan \& Gorgan, 2014; Juhmani, 2017; Tsalavoutas, 2011). We determined the number of applicable requirements for the standards analyzed (IFRS Foundation, 2019a, b) and we assessed the level of compliance by analyzing how the companies respond to each of the requirements. We award 1 for full compliance, 0.5 for partial compliance, 0 for non-compliance and N/A for an item which was not applicable. We compute the overall compliance index as:

Where:

$$
\mathrm{CI}=\frac{\sum_{i=1}^{t} d i}{\sum_{i=1}^{n} d i}
$$

$\mathrm{CI}=$ Compliance index

$\mathrm{di}=$ rating for item $\mathrm{i}$ ( 1 for full compliance, 0.5 for semi-compliance, 0 for noncompliance and N/A for an item which was not applicable)

$\mathrm{t}=$ number of items disclosed

$\mathrm{n}=$ maximum applicable items to be disclosed

The index is unweighted, in order to avoid subjectivity in assessing the importance of the disclosure items.

We focus our investigation on two IFRS, IAS 36 Impairment of assets and IAS 38 Intangible assets, for several reasons. First, these standards were found to be relevant for the pharma industry, as per Lavi (2016). Second, compliance with these standards is considered critical in the accounting literature (e.g., Glaum et al., 2013; Gorgan \& Gorgan, 2014). Moreover, goodwill and impairment are a topic of interest for the IASB, given their work plan ${ }^{\mathrm{i}}$.

Some of the studies involving compliance indexes use check-lists developed and published by Big 4 companies (e.g. Gutierrez Ponce et al. (2016) use an EY checklist from 2012; Gorgan and Gorgan (2014) use a Deloitte "IFRS Presentation and Disclosure Checklist"). We use the check-list developed by EY in 2012 (EY, 2012).

We collect compliance data from the financial statements published on Bucharest Stock Exchange website. Moreover, we collect other financial and non-financial data, for the years and the entire period under study, from the annual report, companies' website and from the media.

The other collected information refer to the auditor reputation and audit opinion (often used in the literature review according to Ben Salem 2017; Glaum et al., 2013; Hope et al., 2008; Nurunnabi, 2015; Păunescu, 2015; Tsalavoutas, 2010), size of the company (total assets) (Garcia-Navarro \& Bastida, 2010; Glaum et al., 2013; Hope et al., 2008), stakeholders' structure (Hope et al., 2008; Bova \& Pereira, 2012; Procházka \& Pelák, 2015; Juhmani, 2017) and stock market capitalization (Ben Salem 2017). All these are regular variables employed in disclosure studies, so they 
are collected to first ensure comparability with other studies, and second to create an understanding of the company's institutional context. Moreover, we look at other company data, such as disclosures about audit committee (existence and membership), intended users and plans, legitimacy issues, changes in shareholders' structure and expectations. We analyze all data following a qualitative approach, by making sense of the changes in various institutional factors over time.

\section{Research results}

\subsection{The institutional context of the case companies}

Our three Romanian-based companies are listed on the Bucharest Stock Exchange, two of them (Antibiotice and Biofarm) on the Premium Tier, and the third one (Zentiva) on the Standard Tier. However, the three of them are in competition, as main listed players in the pharma industry (Cojocar, 2014). Moreover, irrespective of the current ownership, the three pharma companies are among the oldest companies in this industry in Romania. David (2013) analyzes the industry and finds that after Terapia Cluj Napoca, which is the oldest Romanian company in the industry (the company was delisted from BVB in 2004), the three companies investigated follow in the top: Biofarm (founded in 1921), Antibiotice (founded in 1955), and Zentiva (founded in 1962 as Uzina de Medicamente Bucureşti). The three companies have, however, significant differences in their institutional environment, mainly given their ownership and strategy followed after the fall of communism. Table 1 reports some data about the institutional context of the three companies.

Table 1. Institutional characteristics Panel A. Antibiotice SA

\begin{tabular}{lrr}
\hline Characteristic & $\mathbf{2 0 1 3}$ & $\mathbf{2 0 1 7}$ \\
\hline Auditor type & Other audit networks - BDO & Local audit firm \\
Auditor opinion & Qualified & Unqualified \\
Total Assets (M EUR) & 114.07 & 122.96 \\
Market capitalization (M EUR) & 83.53 & 77.51 \\
Shareholders' structure (\%) & 100.00 & 100.00 \\
$\quad$ Romanian Legal Person (\%) & 72.02 & 75.59 \\
Foreign Legal Person (\%) & 6.75 & 7.23 \\
$\quad$ Others (\%) & 21.23 & 17.18
\end{tabular}

Panel B. Biofarm

\begin{tabular}{lrr}
\hline Characteristic & $\mathbf{2 0 1 3}$ & $\mathbf{2 0 1 7}$ \\
\hline Auditor type & Other audit networks - & Other audit networks - \\
& BDO & BDO
\end{tabular}




\begin{tabular}{lrr}
\hline Characteristic & $\mathbf{2 0 1 3}$ & $\mathbf{2 0 1 7}$ \\
\hline Auditor opinion & Unqualified & Unqualified \\
Total Assets (M EUR) & 46.97 & 56.31 \\
Market capitalization (M & 65.94 & 61.75 \\
EUR) & 100.00 & 100.00 \\
Shareholders' structure & 68.10 & 87.83 \\
$\quad$ Romanian Legal Person & - & - \\
$\quad$ Foreign Legal Person (\%) & 31.90 & 12.17 \\
$\quad$ Others (\%) & & \\
$\quad$ Panel C. Zentiva & & $\mathbf{2 0 1 7}$ \\
\hline Characteristic & $\mathbf{2 0 1 3}$ & Big 4 \\
\hline Auditor type & Big 4 & 106.68 \\
Auditor opinion & Unqualified & Unqualified \\
Total Assets (M EUR) & 80.29 & 307.82 \\
Market capitalization (M EUR) & 99.48 & 100.00 \\
Shareholders' structure & 100.00 & - \\
$\quad$ Romanian Legal Person (\%) & & - \\
$\quad$ Foreign Legal Person (\%) & 81.64 & 81.59 \\
$\quad$ Others (\%) & 18.36 & 18.41 \\
\hline
\end{tabular}

Antibiotice SA, the largest (based on total assets) of the three companies, is listed on BVB since 1997 and it is still a state-owned company. The pressures for privatization were stringent in the early decades after the fall of communism, and Antibiotice was close to being privatized. However, a potential corruption case around the privatization stopped it (Ivanov, 2019), and Antibiotice is currently owned by the Romanian state through the Ministry of Health for 53\%, and for around $20 \%$ by various investment funds (SIFs). The free float of the company is around $20 \%$, and the detailed shareholders' analysis shows that the company has some institutional investors as well. The auditor of the company is a mid-tier audit firm (BDO). The audit opinion was qualified for three fiscal years starting 2012. The company has a new auditor starting 2017. During the General Meeting of the Shareholders held on June, $28^{\text {th }}$ 2017, the audit firm Societatea de Contabilitate, Expertiză și Consultanță Contabilă - SOCECC SRL was elected for a period of three years and the reason for the change in audit firm was not specified.

The company struggled with all the changes imposed by the switch from a socialist regime towards a capitalist system, challenges augmented by the fact that it is a stateowned company. The management of the company experienced the old system as 
well (Ivanov, 2019), but significant investments were made and niches exploited in the market. However, the company is internationally recognized as an expert in the field, in some niched areas (idem), by countries like US or China. The reform of the company involved implementing the market-based principles of management and reporting as well. As such, in 2012 the company reports that an audit committee is created. Currently, the audit committee is formed of three representatives of stateowned entities - a doctor from the Ministry of Health, an engineer and an economist from SIFs. Moreover, the company complies with disclosure requirements for investors, being one of the few listed entities obtaining a score of 10 in the 2019 review process (ARIR, 2020).

Biofarm is the smallest company of the three analyzed. The company was privatized in 1997 and in 2005 it was listed on the Bucharest Stock Exchange (David, 2013). However, the privatization process (the buyer was International Pharmaceutical Group) was contested over time ${ }^{\mathrm{ii}}$, which resulted that in $2017,87.83 \%$ of the shares were owned by investment funds (SIFs), SIF Muntenia, SIF Banat-Crisana and SIF Moldova being the main shareholders, with an increasing ownership percentage between 2011 and 2017. In the same period, Biofarm's auditor was the mid-tier audit firm BDO, and the audit opinion was unqualified. Regarding the Audit Committee, the company reported in 2010 that it will have one constituted, which actually happened in the following year, but in 2013 Biofarm reports that "The Audit Committee is being reconstituted". The situation remains the same since 2016, when the company comments in the "Comply or explain" report that "There is currently no Audit Committee set up. It will be constituted to the extent in which the conditions are met and the necessity of its existence appears". Until 2018 no Audit Committee has been set-up (or there is no public disclosure in this respect).

Also, in March 2014, media reported that a delisting from the Bucharest Stock Exchange was possible, as "The $10 \%$ repurchase offer that drug producer Biofarm (BIO) will roll up starting $26^{\text {th }}$ of August prepares the complete control taking over by the SIFs which now cumulatively own about $73 \%$ of the capital, but also the delisting of the company" (Tudor, 2014). These discussions took place in the context in which the SIFs control generated scandals around the people having top positions in the board of Biofarm, and some being highly publicly contested politicians and businesspeople (Pricop, 2014). The company partially complies with disclosure requirements for investors, obtaining a score of 5 out of 10 in the 2019 review process (ARIR, 2020).

Zentiva (previously Sicomed) was privatized in 2000, when the company was bought by a group of institutional investors, through the Cypriot company Venoma Holdings Limited. In 2005, Zentiva N.V. bought Venoma and the shares of Sicomed SA (which was renamed in the meantime as Zentiva SA). After four years, in 2009, Sanofi-Aventis Europe made the announcement that it became the main shareholder for Zentiva N.V., owning $96.8 \%$ of the company and in the same year it "made a 
public offer regarding the purchase of stocks of the issuer Zentiva SA" (Zentiva Annual report, 2017). However, in the annual reports of the company, even in 2017, Venoma Holdings appears as still owning $50.981 \%$ of the company and SanofiAventis Europe only $6.684 \%$. In 2013, Zentiva was subject to a dispute between its minority shareholders (among which are Investment Fund KJK and Pension Fund ING) and the company's management, for granting loans with preferential interest rates, without requesting any guarantees, instead of keeping the money in Romania (Chirileasa, 2013). Zentiva motivated the decision claiming the loans were granted in order to capitalize the cash surplus, on the short term, at fair interest rates and that guarantees were not necessary, as Sanofi Aventis Europe enjoys financial credibility on the financial markets. In response, the minority investors also requested higher dividends, but the majority shareholder voted against this claim. A report on the intra-group transactions was requested, but the claim was rejected as well. Since "usually, parent-companies are those that support through financing the development of local subsidiaries" and "moreover, the loans granted by the parent companies are also included in the calculation of foreign direct investments in Romania" (Chirileasa, 2013), the minority shareholders claim that the parent company simply uses the financial resources of Zentiva SA and asked the board "Why only the majority shareholders should benefit from such loans? We are shareholders as well, why don't you grant us loans under the same conditions?". In November 2016, Sanofi notified the Stock Exchange it will sell the generic drugs division in Europe, including the one in Romania, and in January 2017 it signed a license and medicines supply contract with Sanofi Wintrop Industrie and also provided a license to this company to distribute pharmaceutical products (Popescu, 2017). In April 2017, the Pension Fund NN demands audits, higher transparency and dividends (Popescu \& Ivan, 2017) and in December 2017, the majority shareholder intends to initiate a public offer to buy the remaining shares that are not in their ownership (Ivan, 2017). As at December 2018, the Zentiva Group was owning 93.23\% of the shares of the company.

The Audit Committee of Zentiva SA was constituted in 2017, after the company having claimed in 2012 that "Depending on the future context, the opportunity of creating such a committee will be analyzed" and in 2016 having announced that it will establish an Audit Committee in 2017. During the analyzed period, the auditor of the company was EY and all received opinions were unqualified. However, the company poorly complies with disclosure requirements for investors, obtaining a score of 1.5 out of 10 in the 2019 review process (ARIR, 2020).

\subsection{Compliance scores with identified standards}

We analyzed the compliance levels with IAS 38 and IAS 36 for the 2013 and 2017 financial years. According to the employed methodology, we report the results obtained using the compliance index in table 2 : 
Table 2. Compliance Index

\begin{tabular}{lcrrr}
\hline \multirow{2}{*}{ Company } & \multicolumn{2}{c}{ Compliance Index 2013 } & \multicolumn{2}{c}{ Compliance Index 2017 } \\
& IAS 36 & IAS 38 & \multicolumn{1}{c}{ IAS 36 } & \multicolumn{1}{c}{ IAS 38 } \\
\hline Antibiotice SA & 0.17 & 0.39 & 0.25 & 0.33 \\
Biofarm & 0.50 & 0.50 & 0.50 & 0.39 \\
Zentiva & 0.50 & 0.72 & 0.50 & 0.69 \\
\hline
\end{tabular}

We notice that compliance level for IAS 36 Impairment of assets is low for the three analyzed entities, confirming the conclusions of Larson and Street (2004) that IAS 36 is perceived as one of the most difficult standards to apply in Romania. Information provided was insufficient, thus we are in the position of impossibility to determine whether the entities did not disclose information about impairment tests and losses or reversals, or they did not perform any tests at all. No entity has provided information especially about cash-generating units, discount rates, fair value of the assets or recoverable amount.

Surprisingly, results for IAS 38 Intangible Assets show that the overall compliance level has decreased in 2017, as compared to 2013. For Biofarm for example, we noticed a decrease in the compliance index for the "aggregated amount of research and development expenditure recognized as an expense during the reporting period". In 2013, the required amount was presented in the Informative data section, from the report submitted to ANAF (National Agency of Fiscal Administration - rom. Agenția Națională de Administrare Fiscală), while in 2017 the amount is missing from the same report, even though the company specifies that "during 2017 the activity of licensing/relicensing of new products in the portfolio comprised: renewals of EU numbers in Romania - 5 drugs; 2 food supplements - new formulas" also stating that "The Research and Development Department started the development of 19 food supplements and 2 medicines and provided technical assistance for the manufacture of industrial series for 7 products" (Annual report, 2017:17).

\subsection{Discussion of the levels of compliance}

Based on the empirical archival studies on compliance, some expectations may be expressed in terms of the levels of compliance in association with various variables, such as type of auditor, size, presence on the market, type of shareholders, overall transparency, or the establishment of an audit committee. Some of our results support some of these expectations. For example, Zentiva, the only one with foreign ownership and with a big 4 auditor, has slightly higher disclosure scores. Other results contradict the general compliance expectations. As such, we observe that the general compliance levels with the identified standards decrease over time, while in Romania there has been overall an improvement in enforcement (Albu et al., 2019). Moreover, the companies listed on the premium tier and with higher overall transparency scores (ARIR, 2020), Antibiotice and Biofarm, have lower compliance 
scores than Zentiva. These conflicting results raise questions about the adequacy of studying compliance in Romania using the common hypotheses of developed capital markets.

Moreover, these results open the room for more in-depth analyses, where more complex institutional frameworks (such as Dillard et al., 2004) might be useful. The macro (political and economic level) of Dillard et al. (2004) is transposed into our cases by the applicable laws and formal structures applicable. This overall system might be characterized in Romania by slight improvements over time in the level of enforcement from ASF (ro. Autoritatea de Supraveghere Financiară, en. Financial Supervisory Authority) and increasing expectations from the capital market participants (Albu et al., 2019). However, Romania does not become a fullyfunctioning capital market, since there are varying expectations in terms of the financial reporting role in decision making and tolerance of low compliance and transparency (Albu et al., 2019; ARIR, 2020). All of these features leave room for companies to both comply, or not, with particular accounting standards. Moreover, these companies were confronted to contested privatization processes - some failed (Antibiotice and, to some extent, Biofarm), and some criticized for the outflows towards the parent company (Zentiva), state interventions and corruption cases, which represent, to some extent, a general trait of the Romanian environment.

Moreover, these legitimacy grounds (in terms of low expectations, in our case) are determined at the organizational field (industry) level as well. All these companies, like others in the industry, were subject to both high business prospects and profits (Cojocar, 2013), and corruption cases and allegations. The macro and industry level features provide some explanations for, on the one hand, low levels of compliance with the standards investigated, and, on the other hand, the quite low variation across the three companies studied.

At the organization level, companies incorporate other additional constraints to respond to the macro and industry-level expectations. The construction of the legitimacy on the capital market seems to be determined by many other factors than the quality of financial reporting, including their history and brand, and business prospects. Antibiotice SA is state owned, it has a perfect score in the transparency in relation to investors (ARIR, 2020), but it has a low compliance score in accordance with IAS 36 and IAS 38. This shows that achieving high levels of compliance might be costly, or even difficult, for companies, and that full compliance is difficult to be achieved. Moreover, the response (Albu et al., 2014) depends on various expectations and pressures from different groups. The company is State-owned and has a local auditor, but complied with the requirement to create an audit committee. On the other hand, Zentiva feels the pressures of being a foreign subsidiary (justifying slightly higher accounting compliance scores), but partially complies with 
local expectations (such as transparency in relation to investors and creating an audit committee).

\section{Conclusions}

In this paper we discuss the levels of compliance with two standards (IAS 36 and IAS 38) employing a qualitative research approach and mobilizing an institutionalbased theoretical framework. We analyze the context and compliance scores of three Romanian companies in the pharma sector. We find that overall the three companies display a low level of compliance, and, surprisingly, the level of compliance decreases over time.

Our approach allows us to overcome some of the constraints of conducting archival research to explain variation in compliance, which is the mainstream approach. Particularly, we emphasize the importance of the institutional context in investigating financial reporting in general, and IFRS compliance in particular, in emerging economies. In these countries, general expectations related to associations with the type of auditor, ownership, size, profitability (Bepari et al. 2014; Juhmani, 2017; Glaum et al., 2013; Navarro-Garcia \& Bastida, 2010; Zehri \& Chouaibi, 2013; Uyar et al. 2016) partially explain the compliance scores (Albu et al., 2013; Gorgan \& Gorgan, 2014; Samaha \& Khlif, 2016).

We mobilize features from the socio-economic and industry context to explain the overall level of compliance, including the contested privatizations, legitimacy gained from the brand and company's history, and the overall low expectations in terms of financial reporting compliance. Moreover, we discuss how the difference in organizational factors may justify some differences in compliance. We posit that the company being a foreign subsidiary (Zentiva) and audited by a big 4 firm pays more attention to accounting compliance since it affects as well group's financial statements, even if there are signs of non-compliance or limited transparency in other areas related to financial reporting. On the other hand, the two other companies (Antibiotice and Biofarm) are dominated by local ownership and interests which lead to lower expectations in terms of transparency (state ownership, SIFs presence etc.). However, their lower scores are compensated by legitimacy gained through other forms of transparency, and good business prospects.

Finally, we emphasize that accounting compliance is a compromise, a response to sometime conflicting pressures, and call for more qualitative, institutional based (Guerreiro et al., 2020) research in the context of emerging and less developed economies. 


\section{Acknowledgement}

An earlier version of this paper was presented at the AMIS IAAER international conference, June 5-6, Bucharest, Romania. We thank reviewers and participants for their feedback.

\section{References}

Albu, N., Albu, C.N., Bunea, Ș., Calu, D.A. \& Gîrbină, M.M. (2011) “A story about IAS/IFRS implementation in romania - an institutional and structuration theory perspective", Journal of Accounting in Emerging Economies, vol. 1, no. 1: 76-100

Albu, N., Albu, C.N., Mateescu, R. (2013) "Analiza practicilor de raportare pe segmente - cazul societăţilor cotate la BVB" [The analysis of segment reporting practices - the case of entities listed on the BSE], Audit Financiar, no. 10: $32-38$

Albu C.N., Albu, N. \& Alexander, D. (2014) "When global accounting standards meet the local context - Insights from an emerging economy", Critical Perspectives on Accounting, vol. 25, no. 6: 489-510

Albu, C.N., Albu, N., Hoffmann, S. (2019) "'With a little help from my friends': The creation of a financial reporting enforcement system in an emerging economy", working paper.

Alzeban, A. (2018) "The association between internal audit department characteristics and IFRS compliance", Asian Review of Accounting, vol. 26, no. 3: 336-358

ARIR (2020) VEKTOR - measure of the communication of listed companies with investors, Bucharest: ARIR, available on-line at https://www.irromania.ro/wp-content/uploads/VEKTOR_-rezultate-incl-reevaluarefebruarie_RO.pdf

Arnold, P.J. (2012) "The political economy of financial harmonization: The East Asian financial crisis and the rise of international accounting standards", Accounting, Organizations and Society, vol. 37: 361-381

Ballas, A. A., Skoutela D., \& Tzovas C. A. (2010) "The relevance of IFRS to an emerging market: evidence from Greece", Managerial Finance, vol. 36, no. 11: 931-948

Ben Salem, R., Damak-Ayadi, S., \& Saïhi M. (2017) "Determinants of full IFRS adoption", International Journal of Managerial and Financial Accounting, vol. 9, no. 2: 105-123

Bepari, M.K., Rahman S.F., \& Mollik A.T. (2014) "Firms' compliance with the disclosure requirements of IFRS for goodwill impairment testing: Effect of the global financial crisis and other firm characteristics", Journal of Accounting \& Organizational Change, vol. 10, no. 1: 116-149 
Bova F. \& Pereira R. (2011) "The determinants and consequences of heterogeneous IFRS compliance levels following mandatory IFRS adoption: evidence from a developing country", Journal of International Accounting Research, vol. 11: $83-111$

Carlin, T. M. \& Finch, N. (2010) "Resisting compliance with IFRS goodwill accounting and reporting disclosures: Evidence from Australia", Journal of Accounting \& Organizational Change, vol. 6, no. 2: 260-280

Chirileasa, A. (2013) "Revolta minoritarilor de la Zentiva scoate în faţă creditele date de subsidiare firmelor-mamă" [The revolt of minority shareholders of Zentiva makes visible the loans granted to the parent company by subsidiaries], Ziarul Financiar, May 1, available on-line at https://www.zf.ro/zf-24/revolta-minoritarilor-de-la-zentiva-scoate-in-fatacreditele-date-de-subsidiare-firmelor-mama-10825865

Chirileasa, A. (2013) "Zentiva îşi creditează în continuare acţionarul majoritar cu 40 milioane de lei, în ciuda nemulţumirii minoritarilor" [Zentiva continus to credit their controlling shareolder with 40 million lei, despite minority shareholders' disapproval], Ziarul Financiar, May 26, available on-line at https://www.zf.ro/burse-fonduri-mutuale/zentiva-isi-crediteaza-incontinuare-actionarul-majoritar-cu-40-milioane-de-lei-in-ciudanemultumirii-minoritarilor-10902362

Cojocar, A. (2013) "Topul acţiunilor câştigătoare ale anului 2013: farmaceuticele şi FP au strălucit cu randamente de peste $50 \%$. Impact a înmulţit de 4 ori banii investitorilor" [The top of winning shares in 2013: pharma and FP starred with returns superior to 50\%], Ziarul Financiar, December 23, available on-line at https://www.zf.ro/zf-24/topul-actiunilor-castigatoare-ale-anului-2013farmaceuticele-si-fp-au-stralucit-cu-randamente-de-peste-50-impact-ainmultit-de-4-ori-banii-investitorilor-11809107

Cojocar, A. (2014) "Antibiotice, Biofarm sau Zentiva? Care este astăzi cea mai atractivă acţiune din sectorul farmaceutic?" [Antibiotice, Biofarm or Zentiva? Which is today the most attractive share in the pharma industry?], Ziarul Financiar, March 26, available on-line at https://www.zf.ro/zf-24/antibioticebiofarm-sau-zentiva-care-este-astazi-cea-mai-atractiva-actiune-din-sectorulfarmaceutic- 12331237

David, I. (2013) "Istoria celor mai vechi 10 producători de medicamente. Cele mai vechi două fabrici, Terapia şi Biofarm, au în spate o istorie de 92 de ani" [The history of the 10 oldest drug producers. The oldest two, Terapia and Biofarm, have a history of 92 years], Ziarul Financiar, June 9, available on-line at https://www.zf.ro/companii/istoria-celor-mai-vechi-10-producatori-demedicamente-cele-mai-vechi-doua-fabrici-terapia-si-biofarm-au-in-spate-oistorie-de-92-de-ani-10945699

Dillard, J.F., Rigsby, J.T. \& Goodman, C. (2004) "The making and remaking of organization context. Duality and the institutionalization process", Accounting, Auditing \& Accountability Journal, vol. 17, no. 4: 506-542 
Dorobanțu, B. (2018) “Cegedim: În T2, piața de medicamente din România a ajuns la 3,83 miliarde lei, în creştere cu 16,4\%" [Cegedim: In Q2, the drug industry in Romania achieved 3.83 bil. Lei, with a growth of 16.4\%], Forbes Romania, June 9, available on-line at https://www.forbes.ro/cegedim-t2-piata-demedicamente-din-romania-ajuns-la-383-miliarde-lei-crestere-cu-164-125791

EFPIA (2018) The Pharmaceutical Industry in Figures, available on-line at https://efpia.eu/media/361960/efpia-pharmafigures2018_v07-hq.pdf

EY (2012) "International GAAP Disclosure Checklist. Based on International Financial Reporting Standards in issue at 31 March 2012”, Ernst \& Young IFRS Core tools

Glaum, M., Schmidt, P., Street, D. \& Vogel S. (2013) "Compliance with IFRS 3- and IAS 36-required disclosures across 17 European countries: companyand country-level determinants", Accounting and Business Research, vol. 43, no. 3: $163-2014$

Gorgan, C. \& Gorgan, V. (2014) "Study on disclosure level of companies listed on the bucharest stock exchange in accordance with International Financial Reporting Standards: The case of intangible assets", Annals of the „Constantin Brâncuşi” University of Târgu Jiu - Economy Series, no. 2: 104-115

Guerreiro, M.S., Rodrigues, L.L. \& Craig, R. (2020) "Institutional theory and IFRS: An agenda for future research", Spanish Journal of Finance and Accounting, in press

Gutierrez Ponce, H., Hlaciuc, E., Mateș, D., \& Măciucă G. (2016) “Empirical study of financial disclosure compliance with IFRS: evidence from listed Romanian companies", Journal of Accounting and Auditing: Research \& Practice, vol. 2016: $1-15$

Hope, O.K. (2003) "Disclosure practices, enforcement of accounting standards, and analysts' forecast accuracy: an international study", Journal of Accounting Research, vol. 41: 235-272

Hope, O.K., Kang, T., Wang, T. \& Yoo, Y.K. (2008) "Culture and auditor choice: A test of the secrecy hypothesis", Journal of Accounting and Public Policy, vol. 27: 357-373

Houqe, M. N. \& Monem, R. M. (2016) "IFRS adoption, extent of disclosure, and perceived corruption: a cross-country study", International Journal of Accounting, vol. 51: 363-378

Houqe, N. (2018) "A review of the current debate on the determinants and consequences of mandatory IFRS adoption", International Journal of Accounting \& Information Management, vol. 26, no. 3: 413-442

ICAEW (2014) The effects of Mandatory IFRS Adoption in the EU: A Review of Empirical Research, London: ICAEW

IFRS Foundation (2018) Use of IFRS Standards around the world, IFRS Foundation IFRS Foundation (2019a) IAS 36 Assets Impairment, London: IFRS Foundation IFRS Foundation (2019b) IAS 38 Intangible Assets, London: IFRS Foundation 
Ionașcu, M., Ionașcu, I., Săcărin M. \& Minu, M. (2014) "IFRS adoption in developing countries the case of Romania", Accounting and Management Information Systems, vol. 13, no. 2:311-350

Ivan, D. G. (2017) "Ofertă de nerefuzat: francezii de la Zentiva pun pe masă 268 mil. lei pentru a prelua integral afacerea din România şi a scăpa de acţionarii minoritari. Compania spune că are deja angajamente pentru $10,4 \%$ din companie" [Convincing offer: The Franch people from Zentiva put on the table 268 mil. Lei to take over entirely the Romanian business and to get rid of the minority shareholders. Company says that they have promises for $10.4 \%$ of the company], Ziarul Financiar, December 12, available online at https://www.zf.ro/burse-fonduri-mutuale/oferta-nerefuzat-francezii-zentivapun-masa-268-mil-lei-prelua-integral-afacerea-romania-scapa-actionariiminoritari-compania-spune-angajamente-10-4-companie-16856730

Ivanov, C. (2019) "Povestea Antibiotice Iași, una dintre puținele industrii din perioada comunistă care a scăpat de privatizare și a reuşit să aducă România pe locul I în lume (I)" [The story of Antibiotice Iaşi, one of the few communist companies escaping privatization and manging to bring Romania on the first place in the world], HotNews.ro, May 14, available on-line at https://economie.hotnews.ro/stiri-companii-23140894-video-reportajpovestea-antibiotice-iasi-una-dintre-putinele-industrii-din-perioadacomunista-care-scapat-privatizare-reusit-aduca-romania-locul-lume.htm

Juhmani, O. (2017) "Corporate governance and the level of Bahraini corporate compliance with IFRS disclosure", Journal of Applied Accounting Research, vol. 18 , no. 1 : $22-41$

Kwame Agyei-Mensah, B. (2017) "The relationship between corporate governance mechanisms and IFRS 7 compliance: evidence from an emerging market", Corporate Governance: The International Journal of Business in Society, vol. 17, no. 3:446-465

Larson, R. K. \& Street, D. L. (2004) "Convergence with IFRS in an expanding Europe: progress and obstacles identified by large accounting firms' survey", Journal of International Accounting, Auditing and Taxation, vol. 13, no. 2: 89-119

Lavi, M. R. (2016) The Impact of IFRS on Industry, United Kingdom: John Wiley \& Sons Ltd

Mazni, A., Sulaiman, N.A., Ismail, K., Sapiei, N.S. (2012) "Compliance with International Financial Reporting Standards (IFRSs) in a developing country: Evidence from Malaysia", Asian Journal of Accounting Perspectives, vol. 5, no. 1: 23-34

Mokhtar, E., Elharidy, A. \& Mandour M. (2018) "Compliance with IFRSs: The case of risk disclosure practices in Egypt", Arab Economic and Business Journal, vol. 13: 1-14

Navarro-García, J.C \& Bastida, F. (2010) "An empirical insight on Spanish listed companies' perceptions of International Financial Reporting Standards", Journal of International Accounting, Auditing and Taxation, vol. 19:110-120 
Neagu A. (2018) "Producătorii români de medicamente cer ca industria farmaceutică să fie desemnată domeniu economic strategic de interes național, pentru ca pacienții să nu mai rămână fără medicamente" [The Romanian drugs producers require pharma industry to be named of strategic economic interest to avoid patients' lack of drugs], HotNews.ro, April 20, available on-line at https://www.hotnews.ro/stiri-sanatate-22404793-producatorii-medicamentedin-romnia-cer-industria-farmaceutica-fie-desemnata-domeniu-economicstrategic-interes-national-pentru-pacientii-nu-mai-ramna-faramedicamente.htm

Nurunnabi, M. (2015) "The impact of cultural factors on the implementation of global accounting standards (IFRS) in a developing country", Advances in Accounting, vol. 31 , no. 1: 136-149

Păunescu, M. (2015) "The Romanian audit market structure in case of listed companies and the impact of adopting IFRS", Procedia Economics and Finance, vol. 32: 686-693

Popescu, L. (2017) "Zentiva notifică bursa că a încheiat un contract de livrare produse farmaceutice către Sanofi. Acţiunile scad cu 2,5\%" [Zentiva notifies the stock exchange that they closed a deal to deliver pharma products to Sanofi. Share price declines with 2.5\%], Ziarul Financiar, February 2, available online at https://www.zf.ro/burse-fonduri-mutuale/zentiva-notificabursa-ca-a-incheiat-un-contract-de-livrare-produse-farmaceutice-catresanofi-actiunile-scad-cu-2-5-16147449

Popescu, L. \& Ivan, D. G. (2017) "Fondul de pensii NN atacă politica francezilor la Zentiva şi cere noi audituri, transparenţă, dar şi dividende suplimentare. Acţiunile au crescut la Bursă cu 6\%", Ziarul Financiar, April 12, [The NN pension fund contests the policy of French shareholders of Zentiva and requires new audits, transparency, and additional dividends. Share price increase by $6 \%$, available online at https://www.zf.ro/burse-fondurimutuale/fondul-de-pensii-nn-ataca-politica-francezilor-la-zentiva-si-cerenoi-audituri-transparenta-dar-si-dividende-suplimentare-actiunile-au-crescutla-bursa-cu-6-16230213

Pricop, R. (2014) "După SIF Moldova, Biofarm se delimitează de acuzaţiile aduse lui Andrei Hrebenciuc" [After SIF Moldova, Biofarm distances themselves from the accusations brought to Andrei Hrebenciuc", Ziarul Financiar, October 28, available on-line at https://www.zf.ro/burse-fondurimutuale/dupa-sif-moldova-biofarm-se-delimiteaza-de-acuzatiile-aduse-luiandrei-hrebenciuc-13473351

Procházka, D. \& Pelák, J. (2015) "The development of capital markets of new EU Countries in the IFRS era", Procedia Economics and Finance, vol. 25: $116-126$

PwC (2017) "International Financial Reporting Standards (IFRS) Issues and solutions for the pharmaceuticals and life sciences industries", $\mathrm{PwC}$ 
Samaha, K. \& Khlif, H. (2016) "Adoption of an compliance with IFRS in developing countries: A synthesis of theories and directions for future research", Journal of Accounting in Emerging Economies, vol. 6, no. 1: 33-49

Straut, D. (2018) "România are potenţial în industria medicamentelor: Patronatul producătorilor de medicamente cere desemnarea industriei farma ca domeniu strategic" [Romania has potential in the drug industry: The producers' patronage requires the pharma industry to become strategic sector", Ziarul Financiar, April 22, available on-line at https://www.zf.ro/profesii/romaniaare-potential-in-industria-medicamentelor-patronatul-producatorilor-demedicamente-cere-desemnarea-industriei-farma-ca-domeniu-strategic17140104

Tsalavoutas, I., Evans, L. \& Smith M. (2010) "Comparison of two methods for measuring compliance with IFRS mandatory disclosure requirements", Journal of Applied Accounting Research, vol. 11, no. 3: 213-228

Tsalavoutas, I. (2011) "Transition to IFRS and compliance with mandatory disclosure requirements: What is the signal?", Advances in Accounting, vol. 27, no. 2: 390-405

Tsalavoutas, I., André, P. \& Dionysiou, D. (2014) Worldwide application of IFRS 3, IAS 38 and IAS 36, related disclosures, and determinants of non-compliance, ACCA Research Report 134, ACCA

Tudor, I. (2016) "Biofarm face ofertă de răscumpărare şi e mai aproape de delistare" [Biofarm makes a repurchase offer and it is close to delisting], Ziarul Financiar, August 22, available on-line at https://www.zf.ro/burse-fondurimutuale/biofarm-face-oferta-de-rascumparare-si-e-mai-aproape-de-delistare13133023

Uyar, A., Kılıç, M. \& Gökçen, B. A. (2016) "Compliance with IAS/IFRS and firm characteristics: evidence from the emerging capital market of Turkey", Economic Research-Ekonomska Istraživanja, vol. 29, no. 1: 148-161

Zehri, F. \& Chouaibi, J. (2013) "Adoption determinants of the International Accounting Standards IAS/IFRS by the developing countries", Journal of Economics, Finance and Administrative Science, vol. 18: 56-62

\footnotetext{
${ }^{\mathrm{i}}$ https://www.ifrs.org/projects/work-plan/

ii https://www.zf.ro/companii/avas-obtine-in-instanta-anularea-privatizarii-biofarm3013320
} 